UDC 37.017:004

DOI https://doi.org/10.30839/2072-7941.2018.155555

\title{
HUMAN INTERACTION, CULTURE AND EDUCATION AS A KEY DRIVER OF SUSTAINABLE DEVELOPMENT INFORMATION SOCIETY
}

\author{
(C) NIKITENKO, V.O. \\ Zaporizhzhia State Engineering Academy (Zaporizhzhia, Ukraine) \\ E-mail: vitalina2006@ukr.net, ORCID 0000-0001-9588-7836
}

\begin{abstract}
The urgency of the study of the interaction of man, culture and education in the information society is gaining momentum, as the information society needs to deepen this interaction. This problem arises because people are beginning to rethink the problem of the context of the interaction of culture and education, which affect the person as a creature. The purpose of the study is to conceptualize the interaction of man, culture and education in an information society that requires conditions under which effective interaction is effected that influences the deployment of essential forces in these areas. Formation of the aims of the article: studying the problems of human interaction, culture and education in the conditions of the information society; Identification of the concept of "educational and informational culture" as the coexistence of educational and information culture; an analysis of the interaction of man, culture and education as a value-mutually determined phenomena of human existence, which saturate, enrich and complement each other. An analysis of recent researches and publications from which the solution to this problem was initiated: the use of articles by the authors of V.Andruschenko, T.Andruschenko, O.Bazaluk, A. Boyko, V.Vashkevich, V.Voronkova, L.Gorbunova, O.Kivlyuk, S. Klepko, A. Kravchenko, S. Kutsepal, O. Punchchenko, I. Radionova, N. Skotnoy. Among the Belarusian scientists, we distinguish works by P. Vodopianov, A. Zelenkov, A. Lazarevich, V. Starginsky, V. Tsepkalo. Among the foreign ones are works by Carol Dvec, Richard Florida, Mary Furst and Jurgen Trinks, Eric Brignolfsson and Andrew Macafi, and others. Research methodology is a method of cultural creativity, which contributes to the construction of a model of cultural and innovative education and polity as the main drivers of sustainable development. Scientific novelty - identification of problems of interaction of man, culture and education in the conditions of the information society, contributing to the formation of a new cultural and educational policy as a policy of sustainable development. The results of the research: the interaction of man, culture and education - it is a valuable inter-deterministic phenomena of human existence, which saturate, enrich and complement each other. Therefore, the emergence of the concept of educational culture, and sometimes there is a scientific and educational culture, or educational and information culture, is not accidental in the information age. It is also complemented by the concept of "cultural and educational policy". Conclusion - we formed the concept of interaction of man, culture and education in the information society, based on a new cultural and educational policy that contributes to the formation of a policy of sustainable development.
\end{abstract}

Key words: human interaction, culture, education, new educational policy, new cultural and educational policy, information society

The problem is presented in with important scientific or general terms and its connection practical tasks.

Human interaction, culture and education as a key driver of sustainable development information society 
The interaction of man, culture and education in the conditions of the information society is a process through which the creation of the cultural and educational policy of the information society takes place. Culture and education are among the most important mechanisms of development not only of the individual but also of society as a whole, aimed at the formation and deployment of various forms of physical, cultural and intellectual potential of a person.

An analysis of recent researches and publications, from which the author has started the solution of this problem

The problems of the interaction of man, culture and education in the conditions of the information society were considered through the use of the ideas of B. Andruschenko, T. Andruschenko, O. Bazaluk, A. Boyko, V. Vashkevich, V. Voronkova, L. Gorbunova, O. Kivlyuk, S. Klepko, A. Kravchenko, S. Kutsepal, O. Punchchenko, I. Rodionova, N. Skotnoy. Among the Belarusian scientists, we distinguish works by $\mathrm{P}$. Vodopianov, A. Zelenkov, A. Lazarevich, V. Starginsky, V. Tsepkalo. Among the foreign ones are works by Carol Dvec, Richard Florida, Mary Furst and Jurgen Trinks, Eric Brignolfsson and Andrew Macafi, and others.

The aim of the scientific research is to conceptualize the interaction of man, culture and education in an information society that requires conditions under which effective interaction is effected that influences the deployment of essential forces in these areas.

\section{Formation of the purposes of the} article:

- studying the problems of human interaction, culture and education in the conditions of information societies;

- Identification of the concept of "educational and informational culture" as a coexistence of educational and information culture;

- an analysis of the interaction of man, culture and education as a valued mutually determined phenomena of human existence, which saturate, enrich and complement each other;

- identification of the conditions under which effective interaction is taking place that affects the deployment of essential forces in these areas.

Selection of previously unsettled parts of the general problem to which this article is devoted.

The interaction of man, culture and education takes place in constellation with phenomena-factors of the society - the existences economics - politics. Interaction of culture and education is the result of man's entry into the world, that is, the immersion of man into the sociocultural space; the comprehension by man of the meanings of being, therefore, the task of education is in what and how to teach, in order to awaken in the person the actual human, humane, spiritual, cultural. Interaction of culture and education is the basis of the formation of a person of his image, the formation of a person of his uniqueness and 
individuality; the basis of man's awakening of spirituality, the process and the result of the man's implementation of his universal nature, therefore, without a cultural component, education can not be a complete process in the subject field of the information society.

Methodology.

Constructive methodology of cultural cultivating is a methodology of creative activity, which should be cultivated by the school, and based on designing, constructing the process of cognition and its objects. The basis of constructive methodology is the model and process of construction, which is considered as a cognitive artifact and includes the conceptual (explanatory) and instrumental (prescribing) components of the creative-cognitive process. A model as a project of an object includes not only a reflection or a copy of a certain state of affairs, but also a representation of future practice. Therefore, the author of the object must move from the ideal model of design to the solution of problems in a specific historical, cultural or industrial sphere. The instrumental model of the constructed object acts as an additional value (intellectual value) to the conceptual and represents a system of specific procedures for the transition from "to the right". From the point of view of philosophy, the conceptual model of an object is a theoretical justification of an instrumental model that allows reconstructing various fields in the direction of formation of an information-innovation society, that is, the introduction of innovations.
As the old model (paradigm) of education loses its importance, we have set the goal to show a change in values and attitudes in the transition to an innovative society that is influenced by globalization, which cultivates new points of counting, approaches and values. It is the innovation economy that can become the locomotive of technological and social transformations and the basis for building a competitive society. The essence of the innovation economy is that it requires the formation of a new innovative education based on the use of intellectual resources, which is extremely effective and requires the regeneration of knowledge. We emphasize that innovative development requires innovative education that would promote innovation (diffusion of innovations) and the emergence of appropriate change agents. Diffusion is a process in which innovation over time through certain channels extends among members of the educational (social) system.

\section{Presentation of the main research material with the justification of the received scientific results.}

Philosophical comprehension of the interaction of man, culture and education proceeds from the fact that the main link of the educational process is the person, the place of man in the world and the formation of its cultural achievements due to education. In the broadest sense, education is the process of the mutual transformation of man and the world, as a result of which the world acquires

Human interaction, culture and education as a key driver of sustainable development information society 
the human dimension (the world - for - man, the world - with man), and man becomes an integral part of being (man - in - world, man - for - the world). This is a constant process of meeting a person with the world, resulting in the formation of new forms of their mutual existence and cults.

Interaction of man, culture and education in the subject field of the information society is a problem of improvement of personality, its speech and cultural matrices; Inextricable unity of traditions and innovations; solving a person's problems of his own life, a set of successful or unsuccessful decisions that he takes in the process of overcoming difficulties and needs. So, agreeing with the definition of $\mathrm{H}$. Ortega-i-Gasset, one can generalize that essentially culture characterizes all aspects of human existence.

The concept of "educational and informational culture" is the coexistence of educational and informational culture, which is characterized by the following characteristics:

1) epistemological (synthesis of knowledge, skills and abilities in vocational education, self-education, information technologies, which allows to manage information and generate it in new knowledge);

2) reflexive (analysis of causal relationships in the personal, educational, professional spheres of life);

3) motivating (ensures the stability of the integrated information activity to achieve the consciously chosen path of education);
4) goal-creating (due to the essence of "the person who is constantly developing" and because it asks the vector of personality development);

5) normative-appraisal (maintains a balance in the system of informational and educational activities, reducing the influence of destabilizing factors in the information environment, causing compliance with legal relations).

The interaction of man, culture and education in the subject field of the information society forms a plural theoretical dominant, ideas and beliefs regarding the understanding of education as a cultural phenomenon, and its goals as the introduction of personality to the world of culture and the dialogue between two interrelated systems: "human in culture" and "culture in man "[4].

Modern information reality dictates to us new principles of human existence in society. Modifying the behavioral forms of an individual is a demonstration of the knowledge, skills and abilities obtained to the relevant situation in the world. The actions and activities of the individual, as a member of society, are weapons in the struggle for survival, the desire to adjust to real reality. All available social values that reflect the properties and structure of the civilization in question are an integral part, result or consequence of human functioning.

Interaction of man, culture and education - these are valuable mutually determined phenomena of human existence, which saturate, enrich and complement each other. 
Therefore, the emergence of the concept of educational culture, and sometimes there is a scientific and educational culture, or educational and information culture, is not accidental.

Educational culture is a relatively independent sphere of human existence, which reflects the originality, historicity and specificity of cultural traditions and innovations, which are conditioned by a definite system of values, the level of social activity of people, and the place of the institute of education in society.

Education as a complex dialectical process is studied from a variety of perspectives: cultural, sociological, historical, philosophical, etc. In the sociological aspect, education is seen as a social institution that deals with the preparation, adaptation and attachment of a person to life in a specific society.

Education loses its basic one-time character and acquires the properties of a consistent, systematic, continuous process. Innovative education is knowledge based education that represents it as the main resource: for the knowledge economy, skills and intelligence are the basis of the productive force that allows you to create added value, which is the main objective of a new economy. Innovation education as a potential intellectual resource of society focuses on priorities innovative economic development and determining who to be a specialist in the Internet era and information society.

Education is one of the most important areas of human activity; covers literally the entire society and the costs of it are constantly increasing. In developed countries, in this sphere, $5-8 \%$ of gross national product is invested. UN, in the index characterizing the degree of development of the country, along with the gross product per capita and the average life expectancy of the population, determines the number of literate people and the average number of years of education of its citizens in educational institutions. In society there is an understanding that it is in the sphere of education that the foundations of development strategy are formed not only for each country but also for all humanity. At the same time, the state of education in the modern world is estimated as a crisis that manifests itself in low quality, weak sustainability of knowledge and skills, poor state of their morality and the public, low health of youth, in the widespread youth drug addiction, crime.

It is necessary to highlight the main areas of modern education reforms:

- realization of rapid development of the system of continuous education with the wide use of modern computer technologies;

democratization, fundamentalism, humanization and humanization

education;

- ensuring a high level of natural sciences, mathematics and computer literacy;

- introduction of state standards for all levels of education;

- the implementation of an organic communication system of education 
with public structures and mass media, which are the most important sources of informal education of citizens; - internationalization of education.

The solution to these problems should ensure that the country enters the world economic, political and cultural space.

Education now acquires the basic meanings in the context of what it is:

1) an integral part of the socialization of the individual, in the process of education, a person acquires knowledge, skills, values, norms;

2) a system of information that is included in the educational programs of different schools and educational institutions and is carried out in the process of learning;

3) institutionalized activity, which is provided by a system of educational institutions;

4) the characteristic (or quality) of intellectual development of the population;

5) the level of education of various social groups that determine the economic and cultural objectives of education is the preparation of a person to work in new organizational structures and the widespread use of information technology that changes the organization of work. The goal of education should be to develop teamwork skills; education is seen as a way of solving unemployment problems; education and selfeducation become means of selfrealization of personality. One of the most important issues is the provision of equal opportunities for education by different social groups in the information society [5].

Education acts as a mechanism for ensuring historical heredity, the formation of the translation and imitation of the "social gene pool". Initially, through customs and traditions, and later through knowledge, broadcast the most effective models of life and behavior historically produced by this community. As such a mechanism, education has two essential functions: 1) hereditary, or social reproduction function, which gives young people samples of experience and skills of socially organized life.

Education in the context of the culturological paradigm is interpreted as a cultural process aimed at educating a highly spiritual personality, where spirituality is an axiological component of human existence, within which the education and culture of harmonious functioning and development develop. Functions of preservation and development in the system of education have always been and remain the leaders of the cultural, national, spiritual tradition of society. In terms of philosophy, education is seen as a function of society, which ensures the creation, reproduction and development of society itself, on the basis of the process of translating cultural forms, norms, rules in the course of continuous historical changes.

In our view, it is the philosophical understanding of the social realities of our time, namely its part, of educational culture, that allows us to find answers to the questions that are relevant to a globalized world that is 
constantly transformed under the influence of scientific and technological progress. The globalization dimension of social life in the information society promotes the unification of a person and makes it the same.

Culture is transformed into a "cultural product" and, accordingly, a market economy, the more demand for this product, the sooner it becomes part of the culture of society. So, we are dealing with the cultural crisis of the present, when spirituality is reduced to reason, or even to logic. There is a degradation of society in the context of the loss of spirituality. Modern education has become a set of knowledge, skills and skills for performing specific professional tasks aimed at obtaining a certain "final" result, as a rule, material. Thus, education becomes a subsystem of the economy, which explicitly narrows its functions as a system of formation and education of a full-fledged personality. Therefore, higher education, which becomes global and becomes a mass phenomenon, should not be associated only with professional and career growth of the individual, but should be a minimum necessary to achieve social harmony (harmonization, universalization, consolidation of diversity in the realization of unity), which is constantly requires a person as a full member of society, self-development, and hence self-education, because development without education is impossible.

Education in the conditions of informatization all their efforts should aim at the valuable association of society, which includes various social institutions. And this means that education should go beyond the scope of social institutionalization, which is undergoing a process of global dynamic unevenness and constant limitation of certain time and regulatory boundaries. Before modern education there are several important tasks, namely: adaptation of the individual in a globalizing reality; prevention and neutralization of negative consequences of the influence of ICT on the person and on society in general; to formulate a culturological paradigm of education; popularization and adaptation of the system of values to the present conditions; humanization of the educational process; filling the content of education with an axiological meaning; symbiotic functioning of the triune educational goal: education, development, education; creating a cultural and educational environment that would contribute to the self-realization and self-development of the individual.

In relation to personality, educational culture in the conditions of continuous education is an integrated feature - its creative and intellectual abilities, personal development, reflecting the quantity and quality of accumulated competencies in the relevant field. It is clear that the possibility of learning throughout life puts both before the person - the subject of cultural and educational activities, and in front of educational institutions, new tasks, the solution of which requires additional efforts, which would provide tireless readiness for continuous education 
and its continuation in the forms and using means equivalent to the level of cultural and technical development of society.

Interestingly enough, in our opinion, is the culturological educational paradigm of Academician I. Zazyun. "The essence of the culturological approach in vocational education is to study the human world in the context of its cultural existence, in the aspect of what the world is for a person, what meaning is it for it to fill. It is a study of the cultural fullness of reality, of existing cultural programs. Cultural approach as a concrete scientific methodology of knowledge and transformation is based on the axiology - the doctrine of values and the value structure of the world. Cultural approach is determined by the objective connection of man with culture as a system of values. (...) The key point of the didactic preconditions of the culturological paradigm of vocational education, which applies to the entire system of education and upbringing (principles, content, forms, methods, means), is the sole goal of education - the formation of a coherent picture of the world and the upbringing of harmonious relationships both among individuals, and between social civilizations ".

Education in any society at the time of globalization is an innovative resource, it serves the development of innovative entrepreneurship, the development of IT education, aimed at transforming education into an intellectual (innovative) resource. Serious attention deserves the main problems of innovative education why and how to teach what content, forms and methods should be developed, introducing innovative education. Solving specific problems of innovation development can bring science closer to real problems of socio-economic development.

As for purely educational problems, one should use this form and the relationship of science, education and production, as a case study. One of the priorities remains the commercialization of science. Designing a knowledge-based society involves the development of science as a social institution, the main purpose of which is the production of scientific knowledge, as well as the training of highly skilled specialists. The main task of the development of science in the times of globalization is the realization of the concept of innovative education that would become competitive and released. to the international level. The specificity of the use of innovative education tools - in the symbiosis of modern science, education and business and the formation of the concept of practice-oriented education.

Globalization processes in the world have led to the emergence of a new socio-informational (virtual communication, socio-cultural, information and communication, educational and informational) environment, which requires the formation of a person of a new type, characterized by the relevant features: the ability to adapt, innovation, mobility, creativity, self-education, self-motivation, self-discipline, selfcontrol, competitiveness, creative thinking, where the desire to constantly raise the level of education, 
and not only professional but also top spot. educational culture but to occupy the

\section{REFERENCES}

1. Brinolfsson, E., Makafi, E. (2016). Druha epokha mashyn: robota, prohres ta protsvitannia $\mathrm{v}$ chasy nadzvychainykh tekhnolohiy. Kyiv: FUND, 236.

2. Fezerstoun, M., Lesh, S., Robertson, R. (Eds.) (2013). Hlobalni modernosti. Kyiv: Nika-Tsentr, 400.

3. Kastels, M. (2007). Internet-Halaktyka. Mirkuvannia shchodo Internetu, biznesu i suspilstva. Kyiv: Vyd-vo «Vakler», 304.

4. Kyvliuk, O. P. (2016). Educational culture of the informative society in the context of globalization reality. Humanities Bulletin of Zaporizhzhe State Engineering Academy, 67, 225-232. doi: https://doi.org/10.30839/2072-7941.2016.86827

5. Okinavskaya hartiya global'nogo informacionnogo obshchestva. Available at: http://www.iis.ru/events/okinawa/charter.ru.html

6. Ryzhova, I. (2011). Culture is the most fundamental way of human existence. Humanities Bulletin of Zaporizhzhe State Engineering Academy, 46, 126-134.

7. Nikitenko, V. O. (2013). Geokulturni values in today's world development: a sociophilosophical dimension. Humanities Bulletin of Zaporizhzhe State Engineering Academy, 54, 266-280.

8. Tsili staloho rozvytku 2016-2030. Available at: http://www.un.org.ua/ua/tsilirozvytku-tysiacholittia/tsili-staloho-rozvytku

НІКІТЕНКО, В. О. - кандидат філософських наук, доцент кафедри українознавства i суспільно-філософських наук, Запорізька державна інженерна академія (Запоріжжя, Україна)

E-mail: vitalina2006@ukr.net, ORCID: 0000-0001-9588-7836

\section{ВЗАСМОДІЯ ЛЮДИНИ, КУЛЬТУРИ І ОСВІТИ ЯК КЛЮЧОВИЙ ДРАЙВЕР СТАЛОГО РОЗВИТКУ ІНФОРМАЦІЙНОГО СУСПІЛЬСТВА}

Анотація. Актуальність дослідження взаємодії людини, культури і освіти в умовах інформаційного суспільства набуває все більших обертів, так як інформаційне суспільство потребує поглиблення даної взаємодії. Ця проблема виникає тому, що починають переосмислюватися проблеми людини в контескті взаємодії культури i освіти, які впливають на людину як цілісну істоту. Мета дослідження концептуалізація взаємодії людини, культури і освіти в умовах інформаційного суспільства, що потребують умов, за яких здійснюється ефективна взаємодія, що впливає на розгортання сутнісних сил у цих сферах. Формування цілей статті: вивчення проблем взаємодії людини, культури і освіти в умовах інформаційного суспільства; виявлення поняття «освітньо-інформаційна культура» як співіснування освітньої та інформаційної культури; аналіз взаємодії людини, культури і освіти як ціннісно взаємодетермінованих феномени людського існування, які насичують, збагачують і доповнюють одне одного. Аналіз останніх досліджень і публікацій, 3 яких започатковано розв'язання даної проблеми: використання статей авторів В. Андрущенко, Т. Андрущенко, О. Базалука, А. Бойко, В. Вашкевича, В. Воронкової, Л. Горбунової, О. Кивлюк, С. Клепко, А. Кравченко, С. Куцепал, О. Пунченко, I. Родіонової, Н. Скотної. Серед білоруських вчених ми виокремлюємо твори П. Водоп'янова, А. Зеленкова, А. Лазаревича, В. Старжинського, В. Цепкало. Серед 
зарубіжних - роботи Керола Двека, Річарда Флориди, Марії Фюрст та Юргена Тринкса, Еріка Бріньолфссона та Ендрю Макафі та інших. Методологія дослідження - метод культуротворчості, що сприяє побудові моделі культурно-інноваційної освіти та політики як головних драйверів сталого розвитку. Наукова новизна - виявлення проблем взаємодії людини, культури і освіти в умовах інформаційного суспільства, що сприяють формуванню нової культурно-освітньої політики як політики сталого розвитку. Результати дослідження : взаємодія людини, культури і освіти - це ціннісно взаємодетерміновані феномени людського існування, які насичують, збагачують i доповнюють одне одного. Тому виникнення поняття освітня культура, а подекуди зустрічається і науково-освітня культура, або ж освітньо-інформаційна культура, не $є$ випадковим в інформаційну еру. Воно також доповнюється поняттям «культурноосвітня політика». Висновок - нами сформована концепція взаємодії людини, культури і освіти в умовах інформаційного суспільства, в основі якої нова культурно-освітня політика, що сприяє формуванню політики сталого розвитку.

Ключові слова: взаємодія людини, культури, освіти, нова освітня політика, нова культурно-освітня політика, інформаційне суспільство

НИКИТЕНКО, В. А. - кандидат философских наук, доцент кафедры украиноведения и общественно-философских наук, Запорожская государственная инженерная академия (Запорожье, Украина)

E-mail: vitalina2006@ukr.net, ORCID: 0000-0001-9588-7836

\section{ВЗАИМОДЕЙСТВИЕ ЧЕЛОВЕКА, КУЛЬТУРЫ И ОБРАЗОВАНИЯ КАК КЛЮЧЕВОЙ ДРАЙВЕР УСТОЙЧИВОГО РАЗВИТИЯ ИНФОРМАЦИОННОГО ОБЩЕСТВА}

Аннотация. Актуальность исследования взаимодействия человека, культуры и образования в условиях информационного общества приобретает все большие обороты, так как информационное общество требует углубления данного взаимодействия. Эта проблема возникает потому, что начинают переосмысливаться проблемы человека в контескте взаимодействия культуры и образования, которые влияют на человека как целостное существо. Цель исследования - концептуализация взаимодействия человека, культуры и образования в условиях информационного общества, требующих условий, при которых осуществляется эффективное взаимодействие, что влияет на развертывание сущностных сил в этих сферах. Формирование целей статьи: изучение проблем взаимодействия человека, культуры и образования в условиях информационного общества; выявление понятия «образовательно-информационная культура» как сосуществование образовательной и информационной культуры; анализ взаимодействия человека, культуры и образования как ценностно взаимодетерминированных феноменов человеческого существования, которые насыщают, обогащают и дополняют друг друга. Анализ последних исследований и публикаций, из которых начато решение данной проблемы: использование статей авторов В. Андрущенко, Т. Андрущенко, О. Базалука, А. Бойко, В. Вашкевича, В. Воронковой, Л.Горбунова, О. Кивлюк, С. Клепко, А. Кравченко, С. Куцепал, О. Пунченко, И. Родионовой, Н. Скотной. Среди белорусских ученых мы выделяем произведения П. Водопьянова, А. Зеленкова, А. Лазаревича, В. Старжинського, В. Цепкало. Среди зарубежных - работы Кэрролла ДУЭК, Ричарда Флориды, Марии Фюрст и Юргена Тринкса, Эрика Бриньолфссона и Эндрю Макафи и других. Методология исследования - метод культуротворчества, что способствует построению модели культурно-инновационного образования и политики как главных 
драйверов устойчивого развития. Научная новизна - выявление проблем взаимодействия человека, культуры и образования в условиях информационного общества, способствуют формированию новой культурно-образовательной политики как политики устойчивого развития. Результаты исследования: взаимодействие человека, культуры и образования - это ценностно взаимодетерминированные феномены человеческого существования, которые насыщают, обогащают и дополняют друг друга. Поэтому возникновение понятия образовательная культура, а иногда встречается и научно-образовательная культура, или образовательно-информационная культура, не случайно в информационную эру. Оно также дополняется понятием «культурно-образовательная политика». Вывод - нами сформирована концепция взаимодействия человека, культуры и образования в условиях информационного общества, в основе которой новая культурно-образовательная политика, способствует формированию политики устойчивого развития.

Ключевые слова: взаимодействие человека, культуры, образования, новая образовательная политика, новая культурно-образовательная политика, информационное общество

Стаття рекомендована до публікаиії д.філософ.н., проф. І. С. Рижовою (Запоріжжяь, Україна)

Надійшла до редколегії: 11.12.2018 p. Прийнята до друку: 16.12.2018 p. 